\title{
Slik vurderer \\ offshoresykepleiere egen kompetanse
}

I dag arbeider både intensivsykepleiere, anestesisykepleiere og sykepleiere uten videreutdanning of fshore. Vurderer de sin kompetanse ulikt?

\section{Forfattere}

\section{Bente Lyngfoss}

HMS-koordinator

Eni Norge

\section{Ida Torunn Bjørk}

Professor emerita

Avdeling for sykepleievitenskap, Universitetet i Oslo

\section{Nøkkelord}

\section{Spørreundersøkelse Kompetanse Sykepleierkompetanse Offshoresykepleier}

Sykepleien Forskning 2017 105(62873)(e-62873)

DOI: https://doi.org/10.4220/Sykepleienf.2017.62873

\section{SAMMENDRAG}

Bakgrunn: Sykepleiere som jobber offshore, er ofte eneste helsepersonell om bord på installasjonen og har ansvaret for den medisinske beredskapen. Etter en kraftig reduksjon i antall ulykker offshore på 1980-tallet gikk myndighetene bort fra kravet om videreutdanning i anestesi, eventuelt intensivsykepleie.

Hensikt: Hensikten med studien var å unders $\emptyset$ ke hvordan offshoresykepleiere med forskjellig utdannings- og erfaringsbakgrunn bedømmer sin egen kompetanse til å undersøke, vurdere og behandle pasienter. 
Metode: Vi utviklet et spørreskjema der offshoresykepleiere ble bedt om å vurdere sin egen kompetanse innenfor områdene omsorgskompetanse, medisinsk behandlingskompetanse, medisinsk vurderingskompetanse, teknisk kompetanse, samarbeidskompetanse, valg- og improvisasjonskompetanse samt pedagogisk kompetanse og fagutviklingskompetanse.

Resultat: 66 offshoresykepleiere deltok i en spørreunders økelse om kompetanse. Det var ingen signifikant forskjell mellom anestesisykepleiere, intensivsykepleiere og de med annen eller ingen videreutdanning.

Konklusjon: Til tross for store forskjeller i respondentenes videreutdannings- og erfaringsbakgrunn viste studien ingen forskjell i samlet selvrapportert kompetanse.

Sykepleiere i norsk offshorevirksomhet har ansvar for å undersøke, diagnostisere og behandle pasienter ved sykdom og skade (1). På de fleste offshoreinstallasjonene er sykepleierne alene som helsepersonell. Tidligere var norske myndigheters kompetansekrav at sykepleierne skulle ha videreutdanning i anestesisykepleie, eventuelt intensivsykepleie (2). Dette kravet gikk myndighetene bort fra på 1980-tallet etter at endrete krav til sikkerhet førte til en kraftig reduksjon i antall ulykker med personskade (3).

Myndighetene har ikke undersøkt hvorvidt endringen av kompetansekravene har ført til endringer i helsemessig beredskap på norsk sokkel, men rammeforskriften sier at helsetjenesten skal holde et høyt nivå (4). I denne studien ser vi nærmere på hvordan sykepleiere som arbeider i offshorevirksomhet, selv vurderer sin kompetanse for det arbeidet som kreves på en offshoreinstallasjon.

Vi fant flere artikler med pasientdata fra evakuering av pasienter på norsk og britisk sektor (5-7), men vi fant ikke noen studier som har undersøkt offshoresykepleieres selvstendige vurderinger, behandlingsresultat eller pasienttilfredshet. Artikkelsøkene på norsk og engelsk inkluderte ord som «sykepleier offshore», «medic offshore», «HMSkoordinator», «medevac», «medisinsk evakuering», «offshore helse», «offshore kompetanse» og «sykepleierkompetanse». 


\section{Ulike krav til kompetanse}

For å opprettholde beredskapen pålegges sykepleierne kurs innen akuttmedisin, mens kurs i undersøkelsesteknikk og oppfølging av andre sykdommer og tilstander ikke er et myndighetskrav. Akuttmedisinske tilstander forårsaket av alders- og livsstilsrelaterte helseplager, har økt (8), og er nå den vanligste årsaken til rekvirering av helikopter for å sende pasienter til land. Noen oljeselskaper foretrekker fremdeles spesialsykepleiere med anestesiutdanning eller eventuelt intensivutdanning (9). Andre oljeselskaper ansetter sykepleiere uten videreutdanning og med begrenset klinisk og akuttmedisinsk erfaring til tross for at tariffavtalene for oljeindustrien (10) gir alle sykepleiere samme lønnsplassering som spesialsykepleiere.

\section{三 «Noen oljeselskaper foretrekker fremdeles spesialsykepleiere med anestesiutdanning eller eventuelt intensivutdanning.»}

«Kompetanse» er det sentrale begrepet i denne studien. Cowan og medarbeidere (11) undersøkte hvordan kompetanse har blitt definert i sykepleien. De understreket at en holistisk definisjon som inneholdt kunnskap, ytelse, praktiske ferdigheter og holdninger var nødvendig for å omfatte sykepleiens kompleksitet. Sykepleiere må kunne overføre kunnskap, gjøre grundige vurderinger og tilpasse ferdigheter til uforutsette og ukjente situasjoner (11). 
Eraut (12) beskriver kompetanseutvikling som en trinnvis prosess: Kunnskap og teori systematiseres til standarder innen fagdisipliner, utvikles videre til generaliserte prinsipper, som igjen ligger til grunn for kunnskap om prosesser og retningslinjer. Siste trinn beskriver han som en bevisst prosess med planlegging, problemløsning, analysering, evaluering og beslutningstaking. Dette siste trinnet fungerer ikke ved ensidig bruk av prosedyrer fordi det forutsetter en solid kunnskapsbase, innhenting av informasjon, gjenkjennelse av mønstre og rask tolkning av data (12). Eraut hevder at eksperter tar avgjørelser intuitivt og ikke analytisk, noe som forutsetter betydelig erfaring. En alminnelig oppfatning av kompetansebegrepet er å være kvalifisert til å utføre en jobb, som for eksempel når en person har gjennomført en profesjonsutdanning, mens det forventes ekspertise når noe uventet skjer (12).

For å undersøke hvordan sykepleiere i offshorevirksomheten vurderte sin kompetanse til å undersøke, diagnostisere og behandle pasienter, utviklet vi følgende forskningsspørsmål:

- Vurderer anestesi- og intensivsykepleiere sin kompetanse annerledes enn sykepleiere uten videreutdanning eller med annen videreutdanning?

- Hvilken sammenheng er det mellom selvrapportert kompetanse og tidligere arbeidserfaring?

- Hvilken kompetanse rapporterer sykepleierne at de har mest behov for i sitt arbeid?

\section{Metode}

\section{Design}


For å nå ut til størst mulig antall sykepleiere valgte vi utvalgsundersøkelse som design (13). Metoden baseres på informasjon innhentet gjennom en standardisert utspørring og kan brukes til å samle inn kvantitative data fra store grupper. Et egenadministrert spørreskjema med forhåndsdefinerte svaralternativer egner seg godt til innsamling av data uten at forskeren påvirker deltakerne (14). Utfordringen er å formulere spørsmål som er entydige, og svaralternativer som gjenspeiler området som undersøkes (15).

Det finnes flere måter å undersøke kompetanse på. En systematisk litteraturstudie som kartlegger instrumenter som er brukt til å måle kompetanse, viste at alle instrumentene inneholdt en form for selvevaluering, noen i kombinasjon med andre metoder, som observasjon av praksis, intervju eller evaluering fra leder (15). På grunn av avstand og kostnader valgte vi å bruke et internettbasert spørreskjema.

\section{Utvikling av spørreskjema}

Vi utviklet et spørreskjema som besto av to deler. Del 1 tok utgangspunkt i et skjema av Valeberg, Grønseth og Fagermoen (16) som ble utviklet for å undersøke spesialsykepleieres opplevde kompetanse etter endt utdanning. Deres skjema inneholdt spørsmål fra sju kompetanseområder: omsorgskompetanse, medisinsk kompetanse, teknisk kompetanse, samarbeidskompetanse, pedagogisk kompetanse og fagutviklingskompetanse, valg- og improvisasjonskompetanse samt pårørendekompetanse. Spørsmålene ble tilpasset til de vanligste pasientsituasjonene offshore, unntatt pårørendekompetanse, da ansvaret for pårørende ligger til oljeselskapenes ledelse på land. 
Medisinsk kompetanse ble delt inn i to områder: «Medisinsk behandlingskompetanse» inkluderte spørsmål om bruken av legemidler og evne til å ta selvstendige avgjørelser om oppstart av behandling, og «medisinsk vurderingskompetanse» inkluderte spørsmål om anamnese og undersøkelse som grunnlag for sykepleiernes diagnostisering. De øvrige kompetanseområdene tilpasset vi til sykepleiernes rolle som eneste helsepersonell og leder for den helsemessige beredskapen på installasjonene.

Kompetansedelen i spørreskjemaet besto av 44 spørsmål, og sykepleierne ble bedt om å vurdere seg selv på en Likert-skala (13) fra 1-10 (1 = betydelig gap mellom egen kompetanse og kompetansekrav på jobben, 10 = mestrer kompetansekravene på det aktuelle området på en fullt ut tilfredsstillende måte).

Del 2 av spørreskjemaet besto av spørsmål om alder, kjønn, videreutdanning, tidligere arbeidserfaring og lengden på arbeidserfaring på inntil tre arbeidssteder. Alternativene for videreutdanning var anestesisykepleie, intensivsykepleie, operasjonssykepleie, akuttsykepleie, annen videreutdanning samt paramedicutdanning (for ambulansepersonell) (17). Sykepleierne ble også bedt om å krysse av for hvilken klinisk erfaring de mente var mest relevant da de begynte å jobbe offshore. Styrken i en studie hvor man ser på sammenhenger, regnes som bedre dersom man har flere relevante forklaringsvariabler (13). 
Tre sykepleiere med varierende offshoreerfaring deltok i en pilotundersøkelse for å styrke spørreskjemaets innholdsvaliditet. De ble bedt om å sende skriftlige kommentarer til utformingen av spørreskjemaet, spørsmålsformuleringene og relevansen til kompetanseområdene. På bakgrunn av tilbakemeldingene inkluderte vi spørsmål under området «medisinsk behandlingskompetanse» knyttet til akutt syke og hardt skadde pasienter. Det har sammenheng med at kompetanse til å gjennomføre akuttmedisinsk behandling er et krav til sykepleiernes beredskapsfunksjon offshore $(4,18)$. Dessuten utformet vi flere spørsmål om behandling av vanlige helseplager offshore, som hudutslett, øyeskader, ørenese-hals-problemer, luftveisproblemer, muskel- og skjelettplager (19).

Under «medisinsk vurderingskompetanse» inkluderte vi spørsmål om infeksjonssykdommer, EKG-tolkning, nevrologisk undersøkelse og evne til å gjennomføre undersøkelser det henvises til i Norsk Elektronisk Legehåndbok (NEL) (20). Sykepleierne besvarte spørreskjemaet på ny, og noen spørsmål ble deretter omformulert. Sykepleierne mente at pålogging til nettsiden og formatet på spørreskjemaet var tilfredsstillende.

\section{Datainnsamling}


Vi forsøkte å rekruttere alle sykepleiere som jobbet i norsk petroleumsindustri. Tjue oljeselskaper og bemanningsselskaper som leier ut sykepleiere offshore, ble kontaktet via e-post eller telefon. De seksten selskapene som sa seg villige til å bistå med rekrutteringen, sysselsatte totalt 261 sykepleiere offshore. I denne studien brukte vi et nettskjema som var utviklet ved Universitetet i Oslo. Det forutsatte at spørreskjemaet med pålogging og passord ble sendt elektronisk til informantenes e-postadresser.

Oljeselskapene hadde ulike regler for å gi ut ansattes epostadresser. Noen ga ut e-postlister, mens andre valgte å la HMS-leder, bedriftslege eller koordinator videresende informasjonsskrivet og invitasjonen om å delta til sykepleierne. De som ønsket å delta, tok så direkte kontakt per e-post og ga sitt samtykke, hvorpå de fikk skjema med påloggingsinformasjon tilsendt elektronisk.

Vi samlet inn data mellom november 2013 og mars 2014. Vi purret to ganger - først etter fire uker, deretter etter åtte uker. Besvarelsene ble registrert i en lukket database. Data ble overført elektronisk til SPSS etter lukket inklusjon. Studien er godkjent av Personvernombudet hos Norsk samfunnsvitenskapelig datatjeneste (NSD). I ettertid er deltakernes epostadresser slettet, og dataene er anonymisert.

\section{Analyse}

Alle dataene ble overført elektronisk til IBM SPSS

Statistics 22, som vi benyttet til analysene. Vi analyserte alle utdannings- og erfaringsgruppene med beskrivende statistikk: frekvenser, prosentberegning, gjennomsnitt og standardavvik. Når vi har flere uavhengige variabler i analysen, må vi utføre multiple sammenlikninger. Vi brukte analyse av varians (Oneway ANOVA) for å finne ut om det var signifikante forskjeller i spredningen av svarene både innad i gruppene og mellom gruppene. Vi brukte også Oneway ANOVA for å kunne studere effekten av flere faktorer samtidig. 
I SPSS er Levenes test inkludert i analysen og brukes for å teste nullhypotesen om at det er homogenitet i variansen, slik at gruppene er statistisk sammenliknbare. Vi korrigerte signifikanstestingen med Bonferroni- og T2-korreksjon for å unngå type 1feil, der man feilaktig forkaster nullhypotesen. Signifikansverdi ble satt til $\mathrm{p}<0,05$.

Vi omkodet respondentene til tre utdanningsgrupper: De første to gruppene besto av anestesisykepleiere og intensivsykepleiere. Anestesisykepleiere som også hadde videreutdanning i intensivsykepleie, regnet vi likevel som anestesisykepleiere fordi kompetanse og erfaring med akuttmedisinske prehospitale tjenester ligger til anestesisykepleiernes funksjon (21). De resterende utdanningsgruppene var for små til at vi kunne analysere dem hver for seg og ble derfor slått sammen til én utdanningsgruppe.

Vi omkodet alder og erfaring til tre tilnærmet like store grupper. Klinisk erfaring omkodet vi til mindre erfaring ( $\leq 8$ år), middels erfaring (9-14 år) og lang erfaring ( $\geq 15$ år). Offshoreerfaring ble omkodet til mindre erfaring ( $\leq 4$ år), middels (5-14 år) og lang erfaring ( $\geq 15$ år). Alder ble omkodet til lavest ( $\leq 44$ år), middels (45-53 år) og eldst ( $\geq 54$ år).

\section{Resultat}

Totalt 89 sykepleiere oppga at de ønsket å delta, men kun 66 besvarte spørreskjemaet, hvilket gir en deltakelse på 25,3 prosent av de totalt 261 sykepleierne som arbeidet offshore. I tabell 1 presenterer vi demografiske data om utvalget. 
Tabell 1: Utvalgets sammensetning og bakgrunn

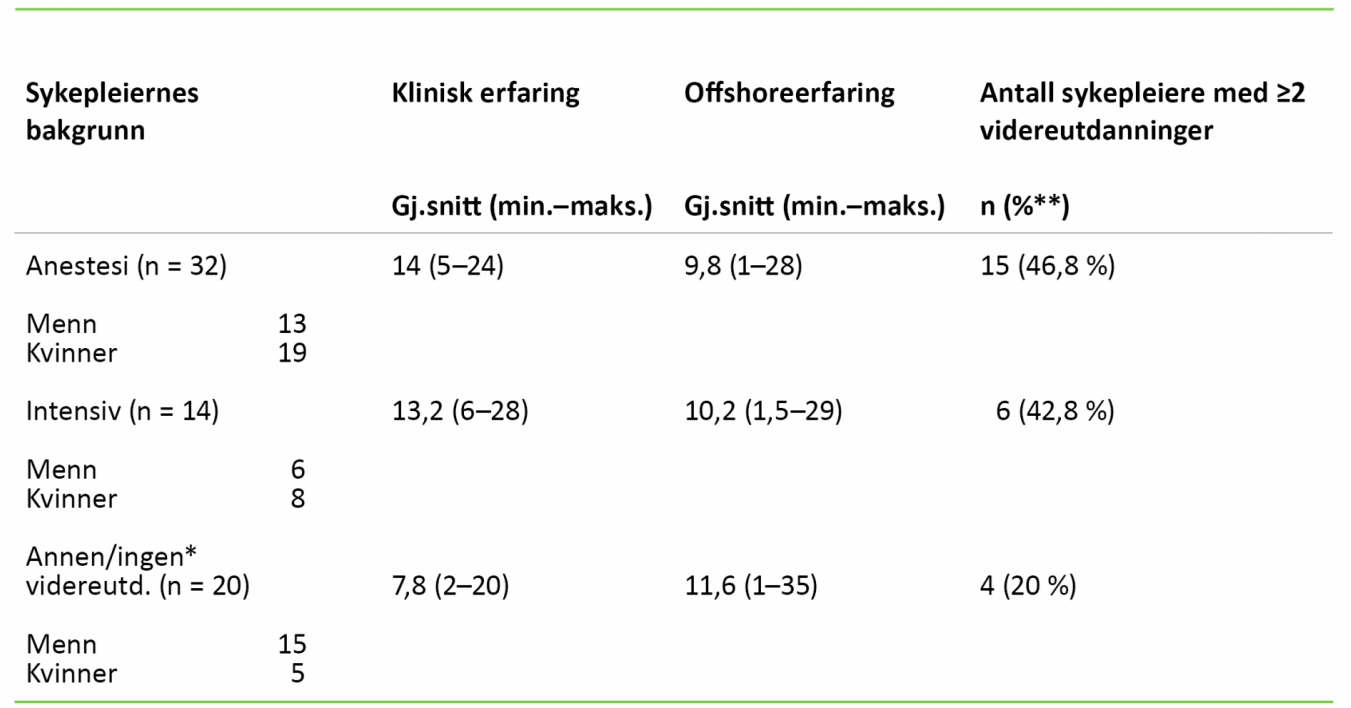

* Resterende utdanningsgrupper ble slått sammen fordi de var for små til å bli analysert hver for seg. ** Prosent i hver utdanningsgruppe.

Utvalget besto av 34 (51,5 prosent) menn og 32 (48,5 prosent) kvinner. Menn og kvinner hadde like mange videreutdanninger, men menn hadde signifikant mindre klinisk erfaring enn kvinner $(p=0,002)$. Tabell 1 viser at gruppen med annen eller ingen videreutdanning hadde kortere klinisk erfaring og færre sykepleiere med flere videreutdanninger enn gruppene med anestesi- eller intensivutdanning.

Noen få sykepleiere hadde videreutdanning i operasjonssykepleie, akuttsykepleie eller paramedicutdanning, men flere av dem hadde i tillegg videreutdanning i anestesisykepleie eller intensivsykepleie. Tjuetre sykepleiere oppga at de hadde annen videreutdanning, som for eksempel kan bety andre typer helsefag, masterstudier eller eventuelt helseledelse. Blant alternativene for klinisk erfaring hadde 59,1 prosent erfaring fra akuttmottak, 48,5 prosent fra anestesiavdeling, 47 prosent fra intensivavdeling og 27,3 prosent fra ambulanseavdeling. 
De første variansanalysene viste at ingen

aldersgrupper, utdanningsgrupper eller

erfaringsgrupper var signifikant forskjellige fra de

andre. For at vi lettere skulle kunne gjøre videre

analyser, omkodet vi alle spørsmålene om kompetanse

til sju variabler tilsvarende de sju

kompetanseområdene i spørreskjemaet. Tabell 2 viser

resultatene fra utdanningsgruppene i alle de sju

kompetanseområdene.

Tabell 2: Variansanalyse med gjennomsnitt for selvrapportert kompetanse

Totalsum for hvert kompetanseområde

Totalsum for hvert
kompetanseoområde $\quad$ Gj.snitt $\quad$ SD $\quad \mathrm{Cl} 95$

\begin{tabular}{|c|c|c|c|c|}
\hline & $\begin{array}{l}\text { Totalsum for hvert } \\
\text { kompetanseområde }\end{array}$ & Gj.snitt & SD & $\mathrm{Cl} 95$ \\
\hline Omsorgskompetanse & 60 & & & \\
\hline Anestesi & & 52,5 & 4,5 & $51-54$ \\
\hline Intensiv & & 52,6 & 4,5 & $49-56$ \\
\hline Annen/ingen videreutdanning & & 51,2 & 5,6 & $49-54$ \\
\hline Medisinsk behandlingskompetanse & 100 & & & \\
\hline Anestesi & & 91,6 & 7,0 & 89-94 \\
\hline Intensiv & & 89,4 & 6,4 & $86-93$ \\
\hline Annen/ingen videreutdanning & & 89,7 & 6,6 & $87-93$ \\
\hline Medisinsk vurderingskompetanse & 90 & & & \\
\hline Anestesi & & 66,9 & 9,7 & $63-70$ \\
\hline Intensiv & & 67,8 & 10,8 & $61-74$ \\
\hline Annen/ingen videreutdanning & & 70,8 & 8,5 & $67-75$ \\
\hline Teknisk kompetanse & 50 & & & \\
\hline Anestesi & & 45,4 & 4,1 & $44-47$ \\
\hline Intensiv & & 45,2 & 4,0 & $43-48$ \\
\hline Annen/ingen videreutdanning & & 44,5 & 4,3 & $42-46$ \\
\hline Samarbeidskompetanse & 50 & & & \\
\hline Anestesi & & 46,1 & 3,7 & $45-47$ \\
\hline Intensiv & & 44,9 & 4,3 & $42-47$ \\
\hline Annen/ingen videreutdanning & & 44,9 & 3,9 & $43-47$ \\
\hline Valg- og improvisasjonskompetanse & 50 & & & \\
\hline Anestesi & & 44,4 & 4,4 & $43-46$ \\
\hline Intensiv & & 43,9 & 3,8 & $42-46$ \\
\hline Annen/ingen videreutdanning & & 44,9 & 3,5 & $43-46$ \\
\hline Pedagogisk kompetanse og fagutviklingskompetanse & 40 & & & \\
\hline Anestesi & & 35,7 & 3,6 & $34-37$ \\
\hline Intensiv & & 34,6 & 3,2 & $33-36$ \\
\hline Annen/ingen videreutdanning & & 34,5 & 3,6 & $33-36$ \\
\hline
\end{tabular}

$(\mathrm{Gj}$.snitt $)$ = gjennomsnittsskår, (SD) = standardavvik, (CI 95) = koeffisientintervall. 
Analyse av variansen viste ingen signifikante forskjeller mellom utdanningsgruppene (p-verdier mellom 0,498 og 1,0). Standardavviket var størst for alle utdanningsgruppene i medisinsk vurderingskompetanse, noe som indikerer at spredningen i svarene var størst i dette kompetanseområdet. Disse respondentene vurderte sin kompetanse noe lavere enn innenfor de andre kompetanseområdene.

I figur 1 tydeliggjør vi forskjellen i spredningen ved å vise svarene omregnet til prosent.

Figur 1: Spredningen i svar for selvrapportert kompetanse for alle respondentene $(n=66)$

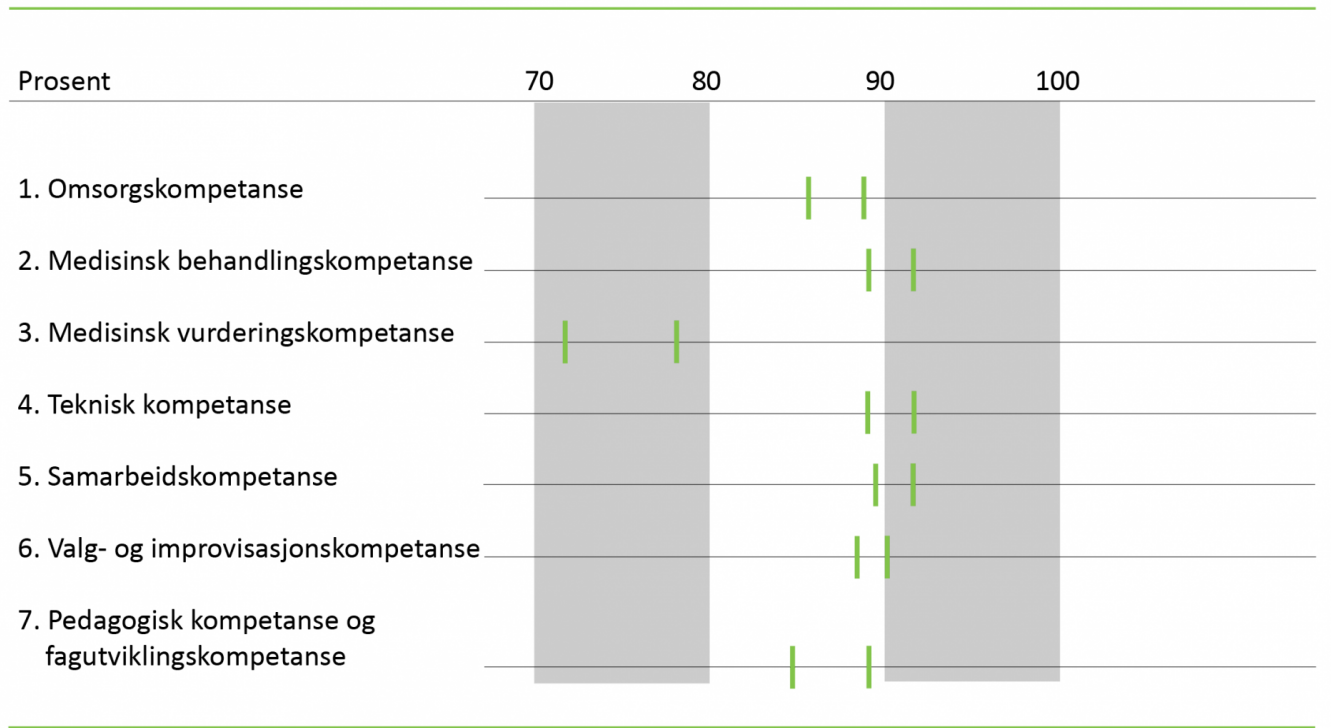

Vi undersøkte også om oppgitte erfaringstyper eller lengden på den kliniske erfaringen, lengden på offshoreerfaringen eller flere videreutdanninger hadde betydning for egenvurdert kompetanse.

Variansanalysen viste at sykepleiere med mindre enn fire års klinisk erfaring vurderte seg like kompetente i alle sju kompetanseområdene som spesialsykepleiere med mer enn 20 års klinisk erfaring. Resultatet for hvert av de 44 kompetansespørsmålene i de tre utdanningsgruppene ble sammenlignet. Kun ett av totalt 10 spørsmål innen gruppen Medisinsk behandlingskompetanse viste signifikant forskjell: Intensivsykepleierne vurderte at de hadde lavere evne til å gjennomføre de akuttmedisinske prosedyrene enn anestesisykepleierne gjorde $(\mathrm{p}=0,037)$. 
På spørsmålet om hvilken klinisk erfaring som var mest relevant for jobben offshore, rangerte de erfaring fra legevakt (92,3 prosent), akuttmottak (87,2 prosent) og operasjonsavdeling (83,3 prosent) høyest.

Respondentene kunne krysse av for inntil tre områder de hadde behov for kompetanse fra. Høyest rangert var ambulansetjenesten (17,6 prosent), med akuttmottak (15,6 prosent) som andrevalg fulgt av poliklinikker (12,6 prosent) på tredjeplass. Tidligere erfaring hadde ikke noe å si for ønsket erfaring.

\section{Diskusjon}

Offshoresykepleierne i dette utvalget vurderte sin kompetanse likt uavhengig av erfaring og videreutdanning. Det ble ikke påvist noen sammenheng mellom type og omfang av tidligere arbeidserfaring og selvrapportert kompetanse i noen av kompetanseområdene. Vi hadde forventet en større varians i sykepleiergruppenes vurdering av egen kompetanse, der de med kort og mindre variert erfaring hadde lavere kompetanseskår. En forklaring kan være at offshoresykepleiere pålegges samme type kurs uansett bakgrunnserfaring, de må hospitere regelmessig på land, og lite akuttmedisin offshore kompenseres med hyppig trening i standardiserte akuttmedisinske protokoller.

\section{三 «Offshoresykepleierne vurderte sin kompetanse likt uavhengig av erfaring og videreutdanning."}


Protokoller og manualer fungerer bra i praktiske treningssituasjoner for personer med lite erfaring (12), og de mindre erfarne sykepleierne kan dermed ha opplevd høy egenkompetanse som følge av at de behersket momentene i protokollene. Det er sannsynlig at når sykepleierne skårer høyt på alle kompetanseområdene i denne studien, reflekterer det bedre de erfarne sykepleiernes kompetanse. Disse skårene tilsvarer en kompetanse som innebærer en unik kombinasjon av teoretisk kunnskap, situasjonsforståelse og profesjonell vurdering $(11,12)$.

Det eneste signifikante funnet var altså at intensivsykepleierne vurderte sin evne til å gjennomføre de akuttmedisinske prosedyrene som lavere enn anestesisykepleierne. Gjennomføring av akuttmedisinske prosedyrer hører til utdanningen og yrkesutøvelsen i begge gruppene (21, 22). En mulig forklaring på denne forskjellen kan være at anestesisykepleiere er trenet $\mathrm{i}$ å etablere sikker luftvei og intravenøs tilgang innenfor og utenfor sitt eget arbeidssted, mens intensivsykepleiere ofte behandler pasienter som allerede er intubert og har kanyler og sentralt venekateter. Forskjellige kriterier for kompetanseoppnåelse er også klart definert i rammeplanene for begge videreutdanningene $(21,22)$.

Intensivsykepleiere deltar vanligvis ikke i traumeteam, derfor var det også forventet en forskjell mellom anestesi- og intensivsykepleierne og de resterende sykepleierne når det gjaldt spørsmålet om evne til å behandle en hardt skadd pasient. At det ikke var noen forskjell, kan skyldes at alle sykepleiere offshore trener på samme traumebehandling. Forskning har vist at det er vanskeligere å evaluere kunnskap enn innøvde praktiske ferdigheter, og det er gjort funn som tyder på at respondenter vurderer seg opp mot sitt mulige potensial, eller de vektlegger innsatsen istedenfor den reelle måloppnåelsen (15).

\section{Medisinsk vurderingskompetanse}


Resultatet for «medisinsk vurderingskompetanse» var noe forskjellig fra de andre områdene, med større spredning i svarene og lavere gjennomsnittskår selv om ingen av resultatene var signifikante. Spørsmålene var rettet mot kompetanse i undersøkelser og vurderinger innen forskjellige medisinske spesialiteter som hører til legenes kompetanseområde, for eksempel å vurdere evnen til å gjennomføre en øyeundersøkelse eller en nevrologisk undersøkelse etter anvisninger fra Norsk Elektronisk Legehåndbok. Kunnskap om at slike undersøkelser eller vurderinger er innenfor en leges kompetanseområde, kan ha medført lavere vurdering av egen kompetanse. Flere forskere har antydet at når respondenter måler sin kompetanse opp mot en gitt standard, her legens kompetanse, vurderer de seg lavere $(23,24)$.

Forskning har vist at det er vanskelig for de minst kompetente å vurdere hva som utgjør høy kompetanse innen et fagområde. De som har mindre utdanning og erfaring fra ett område, har ikke den samme forståelsen for hvor de egentlig ligger i en større sammenheng (24). Samtidig har de mest kompetente en tendens til å tro at en oppgave som er lett for dem, også må være lett for andre. De kan i tillegg ha erfart flere situasjoner der de opplevde at egen kompetanse var utilstrekkelig. Slike situasjoner kan ha ført til at de nedvurderte kompetansen sin i forhold til kollegaer med mindre utdannelse og erfaring $(23,25)$.

\section{三 «Alle vurderte sin kompetanse i akuttmedisin til å være meget god.»}


Respondentene rapporterte at behovet for erfaring fra legevakt og akuttmottak var større enn behovet for erfaring fra spesialiserte akuttmedisinske avdelinger, som anestesi- og intensivavdelinger. Noe som kan ha medvirket til dette, er at det største pasientvolumet offshore består av pasienter som trenger behandling for mindre alvorlige tilstander $(5,19)$. Respondentenes ønske om mer erfaring fra akuttmedisin er likevel ikke i tråd med det faktum at alle vurderte sin kompetanse i akuttmedisin til å være meget god. Offshoreselskapene forventer at sykepleierne de ansetter, fullt ut behersker akuttmedisin, og offshorestillingene er svært attraktive. Vi kan bare spekulere på hva dette manglende samsvaret betyr da vi ikke har funnet forskning som fullt ut belyser det, selv om det i annen litteratur er påvist gap mellom antatt og reelt læringsbehov hos helsepersonell (23).

\section{Studiens begrensninger}

Noen av fordelene med spørreundersøkelser om kompetanse er at det er mulig å få flere respondenter, generere store mengder førstehåndsdata og motta standardiserte svaralternativer som lett kan analyseres $(13,15)$. Ulempen er lav pålitelighet, spesielt hos respondenter med lav kompetanse. Det er også større mulighet for at de som føler seg minst kompetente, ikke deltar, eller at de gir seg selv høyere skår fordi resultatet kan påvirke muligheten for fremtidig jobb (15). Spørreskjemaet vårt er basert på et validert spørreskjema, men vi har gjort noen justeringer i instrumentet som foreløpig ikke er validert.

Prosedyren for rekruttering via selskaper i oljesektoren er den svakeste faktoren ved denne studien, og den lave svarprosenten kan ha virket inn på resultatene. Utsendelse av spørreskjema i sykepleiernes friperioder, selve påloggingsprosedyren og bruk av nettskjema er andre faktorer som kan ha virket negativt inn på deltakelsen.

\section{Konklusjon}


Resultatet av denne spørreundersøkelsen viste ingen forskjell i den samlete selvrapporterte kompetansen hos sykepleierne offshore til tross for store forskjeller i respondentenes utdannings- og erfaringsbakgrunn. Det ble heller ikke påvist hvorvidt tidligere erfaring hadde betydning for selvrapportert kompetanse. På grunn av den lave svarprosenten er resultatet fra denne spørreundersøkelsen ikke generaliserbart, men kan likevel være av interesse da feltet ikke er undersøkt tidligere.

\section{Referanser}

1. Tronsmoen S. Helsetjenesten offshore. Sykepleien 1992;80(3):20-1.

2. Sosialdepartementet. Norm for midlertidig instruks for sykepleier ansatt på anlegg for produksjon m.v. i petroleumsvirksomheten på kontinentalsokkelen [fastsatt av Sosialdepartementet 11. mai 1978]. 1979.

3. Ulven J. Medical and psychological challenges in the offshore petroleum industry. Int Marit Health 2009;60:40-2.

4. Forskrift av 12. februar 2010 nr. 158 om helse, miljø og sikkerhet i petroleumsvirksomheten og på enkelte landanlegg (rammeforskriften). Tilgjengelig fra: https://lovdata.no/dokument/SF/forskrift/2010-0212-158 (nedlastet 21.01.2016).

5. Evensen AMC, Brattebø G. The use of integrated operations in order to improve quality of health care and medical evacuations from offshore installations. [presentasjon] SPE Intelligent Energy Conference and Exhibition, Amsterdam; 2008.

6. Duffy B. Dental problems in the offshore oil and gas industry: A review. Occup Med 1996;46:7983. 
7. Ponsonby W, Mika F, Irons G. Offshore industry: medical emergency response in the offshore oil and gas industry. Occup Med 2009;59:298-303.

8. Gilja A. For syke til å jobbe offshore.

Tilgjengelig fra:

https://sysla.no/offshore/for_syke_til_229_jobbe_offshore/ (nedlastet 07.08.2017).

9. Statoil.com. HMS-koordinator/leder (sykepleier) (7725). Tilgjengelig fra:

https://jobb.tu.no/jobb/hms-koordinatorleder-offshoresykepleier-7725/20519 (nedlastet 07.08.2017).

10. Industri Energi. Lønns og arbeidsvilkår. Tariffavtaler. Flyteriggavtalen NR. Tilgjengelig fra: http://www.industrienergi.no/lonns-ogarbeidsvilkar/tariffavtaler/flyterigg-norsksamleversjon-sokie-2014/ (nedlastet 18.05.2015).

11. Cowan DT, Norman I, Coopamah VP. Competence in nursing practice: a controversial concept - A focused review of literature. Accid Emerg Nurs 2006;15:20-6.

12. Eraut M. Developing professional knowledge and competence. London: Routledge; 1994.

13. Polit DF, Beck CT. Nursing research (int. utg., 9. utg.) Philadelphia: Lippincott Williams \& Wilkins; 2012

14. Lund T, Haugen R. Forskningsprosessen. Oslo: Unipub forlag; 2006.

15. Bing-Jonsson P, Bjørk IT, Hofoss D, Kirkevold M, Foss K. Instruments measuring nursing staff competence in community health care: a systematic literature review. Home Health Care Management Practice 2013;25:282-94. 
16. Valeberg BT, Grønseth R, Fagermoen MS. Spesialsykepleieres opplevde kompetanse etter endt utdanning. Sykepleien Forskning 2009;4:206-213. Tilgjengelig fra:

https://sykepleien.no/forskning/2009/10/spesialsykepleieresopplevde-kompetanse-etter-endt-utdanning (nedlastet 01.08.2017).

17. Høgskolen Betanien. Studietilbud, paramedic. Tilgjengelig fra:

http://www.studiesok.no/paramedic-hogskolenbetanien/ (nedlastet 08.08.2017).

18. Forskrift av 29. april $2010 \mathrm{nr} .613$ om utføring av aktiviteter i petroleumsvirksomheten (aktivitetsforskriften). Tilgjengelig fra: https://lovdata.no/dokument/SF/forskrift/2010-04-29$\underline{613}$ (nedlastet 21.01.2016).

19. Parkinson G. Working as a medic on an offshore oil rig. Intervju av Clare Lomas. Nursing Times 2005;101:76-7.

20. Norsk Helseinformatikk. Norsk Elektronisk Legehåndbok. Tilgjengelig fra: https://legehandboka.no/ (nedlastet 18.08.2017).

21. Kunnskapsdepartementet. Forskrift til rammeplan for videreutdanning i anestesisykepleie. 2005. Tilgjengelig fra: https://lovdata.no/dokument/SF/forskrift/2005-12-01$\underline{1388}$ (nedlastet 01.08.2017).

22. Kunnskapsdepartementet. Forskrift til rammeplan for videreutdanning $\mathrm{i}$ intensivsykepleie.2005. Tilgjengelig fra: https://lovdata.no/dokument/SF/forskrift/2005-12-011389 (nedlastet 01.08.2017). 
23. Colthart I, Bagnall G, Evans A, Allbutt H, Haig A, Illing J, McKinstry B. The effectiveness of self-assessment on the identification of learner needs, learner activity, and impact on clinical practice: BEME Guide no. 10. Med Teach 2008;30:124-45.

24. Jensen, R. Clinical reasoning during simulation: comparison of student and faculty ratings. Nurs Educ Pract 2013;3:23-8.

25. Schlosser T, Dunning D, Johnson Kl, Kruger J. How unaware are the unskilled? Empirical tests of the «signal extraction» counterexplanation for the Dunning-Kruger effect in self-evaluation of performance. J Econ Psych 2013;39:85-100. 